\title{
Effect of Teacher's Qualification on the Performance of Senior Secondary School Physics Students: Implication on Technology in Nigeria
}

\author{
Owolabi, Olabode Thomas \\ Department of Curriculum Studies, Ekiti State University, Ado-Ekiti, Nigeria \\ Tel: 234-803-463-8069 E-mail: otowolabi@yahoo.co.uk
}

Adedayo, Julius Olugbenga (Corresponding author)

Department of Curriculum Studies, Ekiti State University, P.M.B. 5363, Ado-Ekiti, Nigeria

Tel: 234-703-278-1996E-mail: j.oludayo@yahoo.com

Received: February 15, 2012

Accepted: March 15, 2012

Published: June 1, 2012

doi: $10.5539 /$ elt.v5n6p 72

URL: http://dx.doi.org/10.5539/elt.v5n6p72

\begin{abstract}
The study examined the effect of teacher's qualification on the performance of Senior Secondary School students in Physics. The purpose was to determine whether the status of the teacher has any impact on the performance of the students in Physics. The survey type of descriptive research design was adopted. The sample for the study consisted of 100 Senior Secondary Schools Physics students in Ekiti State and the teachers that prepared and presented the students in each school for 2009/2010 West African School Certificate Examination. The year's result summary for each school was collated with the bio-data of their respective Physics teachers. Four hypotheses were postulated and tested at 0.05 significance level. The data collated were analysed using inferential statistics. The results revealed that students taught by teachers with higher qualifications performed better than those taught by teachers with lower qualifications. It was also showed that students performed better in physics when taught by professional teachers. The result also showed that teacher's gender has no effect on their ability to impact knowledge on the students, much as he/she is a skilled teacher in that field of study. However, the experience of the teacher is significant at impacting the students' academic performance in Physics. Based on the findings, it was recommended that experienced teachers with professional qualifications in higher level should teach Physics at the certificate class.
\end{abstract}

Keywords: Effect, Teacher, Qualification, Performance, Students, Physics, Technology

\section{Introduction}

The mastery of a subject is determined by the performance of the students in such a subject at a prescribed examination. Any interactive activity between a teacher and the students is expected to produce learning outcomes in the learners. When such an activity failed to produce a change in behaviour (learning) in the learners, then, there is a problem.

The performance of students in science generally is a major concern to science educators. Aghyeneku in Sakiyo and Sofeme (2008) noted that students' performance in science subjects is low in both national and state examinations. A number of reasons can be identified to be accountable for the poor performance of students in sciences. These include the science curricula, teachers' methods of teaching, parents, government, lack of science facilities and others (Ahiakwo, 2003). Survey from schools (Ajayi, 2007) revealed that inadequacy of good instructional materials, equipment and laboratory facilities in the schools also affect negatively the effective learning of Physics in the schools. According to Ango (1990), students' poor performance in physics globally is basically due to lack of involving the students in the teaching learning activities right from the beginning of any new concept to be taught, lack of qualified teachers as well as experiences in teaching and unavailability and/or insufficiency of materials in the laboratories.

The impact of the teachers in the performance of the students is germane. The teachers are the facilitators who are to impact into the students the concepts expected to be learnt. However, Olarewaju (1986) and Nwagbo (1995) were of the opinion that ignorant of the teachers or neglect of activity- oriented methods by the teachers grossly 
contribute to students' low performance in Physics.

When considering growth in technology, the development of human capital is paramount (Fajonyomi, 2007). This was in line with the view of Ogbazi (1987) who noted that problem of industrial development in Nigeria is that of inadequacy of sufficiently trained human resources and this has been a major constraint on the rate of technological and economic development of the country. The teacher is the major manpower saddled with the responsibility of impacting the concepts considered fundamental to technology through the teaching of these basic concepts from the secondary school. This was why Adeniyi (1993) noted that a country's manpower development depends on the quantity of her well-qualified teachers. As stipulated in the Nigeria National Policy on Education (2004), Physics teaching at the secondary school is meant to develop essential scientific skills in the learners so as to prepare them for technological application in order to stimulate and enhance creativity in them. This laudable objective would not be realized when the students are taught by incompetent teachers. Such teachers would not be able to properly and adequately disseminate the concepts to the students. Physics, being one of the pivotal subjects in technology, its effective teaching must be handled with all seriousness. The competence of the Physics teachers in this regards would be of immeasurable value. One thing is to be well grounded in the conceptual understanding of a subject; another thing is to be well acquitted with the best method to pass the concepts across to the learners for proper comprehension. A professional teacher would be desirable in this regard.

The issue of professionalism in teaching has been on course for quite some decades ago. Scholars argued the necessity of skilled teachers for effective learning. Ngada in Fajonyomi (2007) emphasized that the success or failure of any educational programme rests majorly on the adequate availability of qualified (professional), competent and dedicated teachers. Seweje and Jegede (2005) noted that the ability of a teacher to teach is not derived only from one's academic background but it is based upon outstanding pedagogical skill acquired. The realization of the national growth in technology as highlighted in the Nigeria national policy on education hinges (among others) largely on the quality of the Physics teachers. This view is supported by Nkwodimah's (2003) submission that the teacher's quality will inevitably be seen in the citizens tomorrow. Okebukola in Ngada (2008), while remarking on teachers' quality, observed that over $80 \%$ of respondents in a survey research were of the view that teachers are carriers of weaknesses. These weaknesses include, among others, inadequate exposure to teaching practice, poor classroom management and control, shallow subject-matter and lack of professionalism. From Ajayi's (2009) point of view, the professional qualities of a teacher have to do with the following:

$>$ Mastery of the subject matter

$>$ Sense of organisation

$>$ Ability to clarify ideas

$>$ Ability to motivate students

$>$ Good imagination

$>$ Ability to involve the students in meaningful activities throughout the period of teaching

$>$ Management of the details of learning

$>$ Frequent monitoring of students' progress through tests, formal and informal, written and oral quizzes.

The availability of professional teachers in our schools is low (Ngada, 2008). The reasons may not be farfetched. Teaching is seen as a dumping ground for any unemployed school leavers, irrespective of their area of specialization. This group of able bodied young men and women thus handle the job as a bye-pass venture to their desired ends. Consequently, their input on the job would be very low since it lacks the dedication demanded by the job. The few ones that seem to show little dedication lack the technical knowhow of teaching since they were never trained on the job. The resultant effect on the students' performance is catastrophic. The major evil done by this is half-backed and shallow-knowledge students who often perform poorly in their examinations. This eventually culminates to a decline in the national technological growth.

The issue of gender differences is paramount to educational researchers nowadays. There had been divergent views and reports as to the comparative ability of male and female in human endeavours, especially in education. A survey conducted by Ogbonnaya and Okunamiri (2008) on administrative effectiveness of male and female principals in Imo state, Nigeria revealed that female principals are more effective than their male counterparts in the management of instructional programmes, staff personnel administration, students personnel administration, management of finance and management of physical resources while the male principals are better in school-community relationships. Fauth (1984) also noted that women have been found to be more concerned than men about the academic achievement of students and participate more in professional growth activities. Adedayo 
(1997) however observed that regardless of school gender type, male students did better than female students in all science subjects.

\section{Statement of the Problem}

Physics is one of the major subjects meant to provide the basic concepts needed to enhance the development of technology in the country. Research reports (Ajayi 2004, Adedayo 2008) revealed that the performance of students in Physics is very appalling, hence, calls for attention. The consequence of this might result from unqualified teachers handling this subject in the secondary schools.

\section{Purpose of the Study}

The study investigated the effect of teachers' qualification on the performance of students in Physics at the Secondary School level. It compared the performances of students in Physics between those taught by professional teachers and those taught by non-professional teachers.

\section{Research Hypotheses}

The following hypotheses were generated and tested at 0.05 level of significance.

$\mathrm{Ho}_{1}$ : There is no significant difference in the performance of secondary schools Physics students between those taught by teachers with high qualification and those taught by teachers with low qualification.

$\mathrm{Ho}_{2}$ : There is no significant difference in the performance of secondary school Physics students between those taught by skilled teachers and those taught by unskilled teachers.

$\mathrm{Ho}_{3}$ : There is no significant difference in the performance of secondary school Physics students between those taught by male and female skilled teachers.

$\mathrm{Ho}_{4}$ : There is no significant difference in the performance of secondary school Physics students between those taught by long time experience and short time experience skilled teachers.

\section{Methodology}

The study employed a survey type of descriptive research. It collected data that were already on ground. The population consisted of all students who took Physics in 2009/2010 West African School Certificate Examination in Ekiti State and the teachers that prepared and presented the students for the examination. The sample for the study consisted of 100 Senior Secondary Schools and their Physics teachers who were randomly chosen through purposive and stratified techniques across the state. There were 72 male and 28 female physics teachers in the sample. Stratified sampling was used to select different categories of Physics teachers such as graduate, polytechnic and NCE; skilled and unskilled; male and female and teachers' years of experience. Purposive random sampling is considered appropriate since only Physics teachers that prepared and presented the students for the external examination and their students are required for the study. The year's results summary of each school was collected through the schools' registrars while the teachers supplied their bio data. Teachers with Nigerian Certificate in Education (NCE) and Ordinary National Diploma (ND) are regarded as low qualification levels while Higher National Diploma (HND) and University Degrees are considered to be high qualification levels. Teachers with education background i.e. NCE and B.Sc. (Ed) or B.Ed. are regarded as skilled and professional teachers while others are classified as unskilled teachers. Long time experience teachers are those that have spent at least five years in teaching while teachers with less than five years are considered as short time experience teachers. The data were analysed using frequency counts and mean while t-test statistics were used to draw the inferences.

\section{Results}

$\mathrm{Ho}_{1}$ : There is no significant difference in the performance of Secondary School Physics students between those taught by teachers with high qualification level and those taught by teachers with low qualification level.

Table 1 shows that t-cal (12.86) is greater than t-table (1.98). Thus, the null hypothesis is rejected. This means that there is a significant difference in the performance of secondary school Physics students between those taught by teachers with high qualification level and those taught by teachers with low qualification level.

$\mathrm{Ho}_{2}$ : There is no significant difference in the performance of secondary school Physics students between those taught by skilled teachers and those taught by unskilled teachers.

Table 2 shows that $\mathrm{t}$-cal (8.32) is greater than the t-critical value (1.98). The null hypothesis is therefore rejected which means that there is a significant difference in the performance of students in secondary school Physics between those taught by skilled teachers and those taught by unskilled teachers.

$\mathrm{Ho}_{3}$ : There is no significant difference in the performance of secondary school Physics students between those 
taught by male and female skilled teachers.

From table 3 above, t-cal (1.60) is less than the t-critical (2.021). The null hypothesis is not rejected, meaning that there is no significant difference in the performance of secondary school Physics students between those taught by male and female skilled teachers.

$\mathrm{Ho}_{4}$ : There is no significant difference in the performance of secondary school Physics students between those taught by long time experience and short time experience skilled teachers.

Result of table 4 revealed that t-cal (9.47) is greater that the t-table (1.98). Therefore, the null hypothesis is rejected. This implies that there is no significant difference in the performance of secondary school Physics students between those taught by long time experience and short time experience skilled teachers.

\section{Discussion}

The results of this finding revealed that teachers' qualification level has impact on students' performance in secondary school Physics. This is in agreement with Olarewaju (1986) who submitted that students' low performance in Physics is due to the teachers' ignorant. Adeniyi (1993) also supported the findings when he observed that the manpower development is a function of qualified teachers.

The finding also showed that professional teachers affect the students' performance positively more than the unprofessional teachers. The professional teachers' background training in education is the bane behind this clear cut difference. No wonder, Fajonyomi (2007) in his study, remarked that the success of any educational enterprise depends largely on the availability of professional teachers. This is possible because the trained teachers have been taught the technical knowhow for effective learning to take place in the learners. Scholars are of the opinion that students respond to a particular subject in relative to the kind of

It is also evident from the outcome of the finding that students' performance in physics is unaffected by the teachers' gender but by their skillfulness on the prescribed field of study. This is in line with the finding of Adedayo (2008) that gender has nothing to do with academic ability. The major factors that could affect academic attainment according to Adedayo (2008) included family background, personal interest, school environment and peer group. So, since the teachers (both male and female) are professional teachers, there is no difference in their ability to impact knowledge in the students. This is in accordance with Heller and Parsons (1981) who found that there is no difference in the feedback obtained from a stimulus given to male and female.

The result of this finding also showed that experience counts in the efficiency of the teachers. The teachers with long years of teaching experience were able to impact more on the students than teachers with short years of teaching experience. This is obvious from their mean scores of 71.20 and 69.50 respectively. The closeness of their mean scores could be due to the fact that both are professionally skilled to teach physics. So, the basic rudiments of physics and the pedagogical wherewithal are there for both groups.

\section{Conclusion}

It can be concluded from the results of this study that teacher's academic qualification only is not enough to positively affect academic performance of secondary school students but a professional qualification in a specified field of study. Though, this study showed that gender differences of the teachers has no effect on their ability to impact knowledge, experience however, cannot be jettisoned when considering teacher's effectiveness.

\section{Recommendation}

Based on the findings of this study, the following recommendations were made:

1. Teachers with professional qualification(s) at higher level should teach Physics in the secondary schools.

2. Government should encourage the professional teachers especially in Physics through incentives and worthwhile science allowance.

3. Practicing Physics teachers who are not professional should undergo in-service training such as seminars, Post Graduate Diploma Course in Education e.t.c. for effective discharge of their duties.

\section{References}

Adedayo, J. O. (2008). Effect of Electronics Artisans' Background and Competence on Science and Technology Advancement in Nigeria. Research in Curriculum Studies, 5(1), 132-136.

Adeniyi, E. O. (1993). Trends in teachers' education. In U.M.C. Ivowi (Ed), Curriculum Development in Nigeria. Ibadan. Sam Bookman.

Ahiakwo, O. (2003). Science, science education and scientific literacy. [Online] Available: 
http/:www.unn.edu.net/DEPT/dept-scienceedu.html (December 20, 2011)

Ajayi, P. O. (2007). Evaluation of the implementation of senior secondary school physics curriculum in south west Nigeria (Unpublished Ph. D thesis). University of Ado-Ekiti, Nigeria.

Ajayi, O. S. (2009). Effective Teaching of Physics. A paper presented at a seminar on effective teaching of science in Ekiti State organized by Ekiti State Ministry of Science and Technology, Ado-Ekiti.

Ango, M. (1990). Basic science laboratory with practical suggestions and procedures. Lagos: Hinders.

Fajonyomi, A. A. (2007). Reviving higher education relevance in Nigeria. A paper presented at the 3rd Faculty of Week and Annual National Conference, Faculty of Education. University of Maiduguri on the theme Higher education reforms in Nigeria from 26th to 27th September.

Fauth, G. C. (1984). Women educational administration: A research profile. The Education Forum, 59, 61-67.

Federal Republic of Nigeria. (2004). Nigeria National Policy on Education (Revised Edition). NERC. Yaba Lagos.

Jegede, S. A. (2009). Towards improving skill acquisition during students' industrial work experience scheme programme. National Association of Women in Academics, 1(1), 46- 54.

Ngada, A. J. (2008). Impact of NCE programme on preparation and performance of nce graduate teachers in Borno state Junior Secondary Schools. Research in Curriculum, 5(1), 190-195.

Nkwodimah, M. (2003). Teacher education for the $21^{\text {st }}$ century. In Enoch, A. (Eds), Teacher Education and UBE. Jos: Saniez Publications.

Nwagbo, C. (1995). Effect of guided inquiry and expository teaching methods on the achievement in and attitude to biology of students of different scientific literacy. [Online] Available: http:/www.pepreal.cl/FIE/pdf /lopbc /nwagbo.pdf

Ogbazi, J. N. (1987). Using co-operative education students' performances. Vocational Education Journal, 1(1), 162-169.

Ogbonnaya, C. N., \& Okunamiri, P. O. (2008). Comparative Study of Administrative Effectiveness of male and female principals in Okigwe Education WNE of Imo State. Nigeria Journal of Counselling and Applied Psychology, 4(1), 70-84.

Olarewaju, A. O. (1986). Census of students' under-achievement. 27th Annual conference proceedings of the Science Teachers' Association of Nigeria, 80-87.

Omotayo, K. A. (2009). An investigation into the acquisition of scientific attitude among Junior Secondary School students. National Association of Women in Academic, 1(1), 82-89.

Sakiyo, J., \& Sofeme, R. J. (2008). Effectiveness of science technology society and traditional science teaching methods on students' performance in Yola metropolis, Adamawa state. Research in Curriculum, 5(1), 11-17.

Seweje, R. O., \& Jegede, S. A. (2005). Science Education and Science Teaching Methods. Lagos: Atlantic Association.

Table 1. t-test analysis of teachers' qualification level and students' performance

\begin{tabular}{|l|l|l|l|l|l|l|}
\hline \multicolumn{1}{|c|}{ Variables } & $\mathrm{N}$ & $\overline{\mathrm{X}}$ & $\mathrm{df}$ & $\mathrm{t}_{\text {cal }}$ & $\mathrm{t}_{\text {tab }}$ & Result \\
\hline High Qualification level & 60 & 68.00 & 98 & $12.86^{*}$ & 1.98 & Significant \\
\hline Low Qualification level & 40 & 50.42 & & & & \\
\hline
\end{tabular}

Significant at $\mathrm{p}>0.05$

Table 2. t-test analysis of teachers' skill and students' performance

\begin{tabular}{|l|l|l|l|l|l|l|}
\hline \multicolumn{1}{|c|}{ Variables } & $\mathrm{N}$ & $\overline{\mathrm{X}}$ & $\mathrm{df}$ & $\mathrm{t}_{\text {cal }}$ & $\mathrm{t}_{\text {tab }}$ & Result \\
\cline { 1 - 3 } Skilled Teachers & 45 & 72.60 & 98 & $8.32 *$ & 1.98 & significant \\
\cline { 1 - 3 } Unskilled Teachers & 55 & 53.00 & & & & \\
\hline
\end{tabular}

Significant at $\mathrm{p}>0.05$ 
Table 3. t-test analysis of teachers' gender and students' performance

\begin{tabular}{|l|l|l|l|l|l|l|}
\hline \multicolumn{1}{|c|}{ Variables } & $\mathrm{N}$ & $\overline{\mathrm{X}}$ & $\mathrm{df}$ & $\mathrm{t}_{\mathrm{cal}}$ & $\mathrm{t}_{\text {tab }}$ & Result \\
\cline { 1 - 6 } Male Skilled Teachers & 25 & 78.35 & 43 & 1.60 & 2.021 & Not significant \\
\cline { 1 - 3 } Female Skilled Teachers & 20 & 75.80 & & & & \\
\hline
\end{tabular}

Significant at $\mathrm{p}<0.05$

Table 4. t-test analysis of teachers' years of experience and students' performance

\begin{tabular}{|l|l|l|l|l|l|l|}
\hline \multicolumn{1}{|c|}{ Variables } & $\mathrm{N}$ & $\overline{\mathrm{X}}$ & $\mathrm{df}$ & $\mathrm{t}_{\mathrm{cal}}$ & $\mathrm{t}_{\text {tab }}$ & Result \\
\hline Long Time Experience & 36 & 71.20 & 98 & $9.47^{*}$ & 1.98 & significant \\
\cline { 1 - 4 } Short Time Experience & 64 & 69.50 & & & & \\
\hline
\end{tabular}

Significant at $\mathrm{p}>0.05$ 